\section{Case Reports in Dermatology}

\title{
Non-Melanoma Skin Cancers at Sites of Previous Frostbite: Case Report and Review
}

\author{
Khalel Imanbayev ${ }^{a} \quad$ Abay Makishev ${ }^{a} \quad$ Murat Zhagiparov $^{a}$ \\ Pauline McLoone ${ }^{b}$ \\ ${ }^{a}$ Department of Oncology, Medical University of Astana, Astana, Kazakhstan; \\ ${ }^{b}$ Department of Biomedical Sciences, Nazarbayev University School of Medicine, \\ Astana, Kazakhstan
}

\section{Keywords}

Skin cancer $\cdot$ Cold injury $\cdot$ Frostbite $\cdot$ Carcinogenesis

\begin{abstract}
The association between ultraviolet radiation exposure and skin cancer is well established. Limited studies have reported an association between frostbite and the development of nonmelanoma skin cancer but evidence for a proven link is insufficient and possible carcinogenic mechanisms have not been fully explored. In this report, 3 cases of non-melanoma skin cancer ( 1 case of basal cell carcinoma and 2 cases of squamous cell carcinoma of the skin) which developed at a site of previous frostbite caused by exposure to extremely cold temperatures in Astana, the capital city of Kazakhstan, are described.

(C) 2018 The Author(s)

Published by S. Karger AG, Basel
\end{abstract}

\section{Introduction}

The incidence of basal cell carcinoma (BCC) and squamous cell carcinoma of the skin (SCC), the two main types of non-melanoma skin cancer (NMSC), continues to rise globally $[1,2]$. Throughout the world, the incidence varies considerably with the highest rates of BCC being reported in Australia at $>1,000$ per 100,000 population and the lowest rates in parts of Africa ( $<1$ per 100,000 population) [3]. In the United States, more than 3 million new cases 
of NMSC were recorded annually, making NMSC the most common type of cancer in the US region [4]. In Kazakhstan, NMSC is reportedly the second most common cancer in the country after breast cancer, with incidence figures of 23.3 per 100,000 population [5]. Interestingly, the incidence in the north of Kazakhstan is greater than in the south $(39.8$ per 100,000 vs. 7.8 per 100,000 ). Astana, the current capital city, which lies at latitude $51.6 \mathrm{~N}$ and longitude $71.47 \mathrm{E}$, has a reported incidence of 11.4 per 100,000. Like other regions in the world, the incidence of NMSC is increasing in Kazakhstan, with an annual increase of $17.9 \%$ [5].

The most important risk factor for BCC and SCC is ultraviolet radiation (UVR) exposure, particularly for individuals with skin type I, red or blonde hair, and light-colored eyes [6, 7]. Sequencing of DNA from SCCs and BCCs showed that many of the mutations were UV signature mutations such as $\mathrm{C}>\mathrm{T}$ or $\mathrm{CC}>\mathrm{TT}[8,9]$. Despite the well-established link with UV, research has shown that the relationship between UV exposure and NMSC development is complex. For example, in one study, episodes of severe sunburn in childhood were reported to increase the risk of developing BCC, whilst sunburn in adulthood was found not to be associated with BCC development, suggesting that UV exposures in early life play a more important role [10]. For SCC, long-term cumulative exposures have been shown to be more important [11]. More recently, an association between vitamin D receptor polymorphisms and NMSC risk has been reported, suggesting a potential role for vitamin D in protection from NMSC [12]. Other factors known to increase susceptibility to NMSC include arsenic ingestion, exposure to ionizing radiation, immunosuppression associated with organ transplantation, psoralen plus UVA therapy (PUVA), and a family history of skin cancer [6, 10, 1316].

Despite extensive research on UVR exposure and skin cancer, there is limited information on the effects of cold injury from exposure to extremely cold temperatures on the development of NMSC. One of the first articles describing an association between frostbite and skin cancer was published in 1982 [17]. In this article, 10 cases of SCC were reported on a site previously affected by frostbite (the heel). Another case report published in 1986 described a case of SCC at the site of a frostbite scar [18]. Furthermore, there have been reports of Korean War veterans developing SCC at sites of frostbite after exposure to extreme cold in Korea in the 1950s [19].

In this report, 3 cases of NMSC ( 1 case of BCC and 2 cases of SCC) which developed at a site of previous frostbite caused by exposure to extremely cold temperatures in Astana are described.

Astana is the second coldest capital city in the world after Ulaanbaatar in Mongolia and has an extreme continental climate with warm summers and long, very cold winters. Summer temperatures occasionally reach $+35^{\circ} \mathrm{C}$, while temperatures of $-35^{\circ} \mathrm{C}$ are not uncommon in the winter. January is the coldest month when temperatures as low as $-54^{\circ} \mathrm{C}$ have been recorded.

\section{Case Presentation}

\section{Case 1}

A 54-year-old Caucasian woman developed frostbite on her nose after being outside for approximately $3 \mathrm{~h}$ in temperatures of $-45^{\circ} \mathrm{C}$ (average). The skin on the nose initially turned pale, followed by desquamation and ulceration that failed to heal (Fig. 1). Six months after the initial frostbite injury, she attended the Astana Oncology Center where an incisional biopsy of the lesion was performed and the histological diagnosis concluded BCC. 
Case 2

A 65-year-old Caucasian woman developed frostbite on her right cheek after waiting at the bus stop in temperatures of approximately $-42^{\circ} \mathrm{C}$ (average). Frostbite occurred within $1 \mathrm{~h}$ and initially presented as a white patch on the right cheek. Over time, the lesion developed into a scaly erythematous patch with irregular borders (Fig. 2). The lesion failed to heal and the patient was referred to an oncologist at the Astana Oncology Center 2 years after the frostbite occurred. Biopsy was performed and the specimen was sent for histopathological analysis. The diagnosis was a superficial SCC.

Case 3

Approximately 20 years ago, a 72-year-old Caucasian man developed frostbite whilst hunting in cold, dry, windy conditions at temperatures of around $-35^{\circ} \mathrm{C}$. Frostbite appeared after roughly $1 \mathrm{~h}$ of extreme cold exposure and presented initially as a white patch which later turned red. The lesion failed to heal, and after approximately 1 year, multiple scattered crusted plaques developed on the forehead at the site of previous cold injury (Fig. 3). Around 20 years after the frostbite incident, the man attended the Astana Oncology Center where an incisional biopsy was performed and a diagnosis of invasive SCC was made.

\section{Discussion}

This report describes 3 clinical cases where the diagnosis and medical history revealed an NMSC at the site of previous frostbite and suggests a possible association between cold injury and the development of NMSC. At the same cancer center, 538 NMSC cases were diagnosed between January 2007 and October 2016. In only 3 of these cases was a history of frostbite at the cancer site identified; therefore, the number of cases linked to frostbite is small. One possibility is that cold injury could promote the development of NMSC induced by UVR. Another possibility is that frostbite can induce modifications to DNA resulting in the development of cancer. Alternatively, the association is coincidence but further research and awareness is required to determine if the connection is real or not. UVR is the major environmental causative factor for the induction of NMSC and is known to induce a range of acute and chronic effects on the skin. Acute effects of UVR include DNA damage/mutations, erythema, inflammation, immune suppression, vitamin D synthesis, and melanogenesis. Chronic effects include photo-aging and photo-carcinogenesis, the latter of which can be induced by DNA damage and photo-immunosuppression [20]. DNA is known to absorb UVR optimally between the wavelengths 245 and $290 \mathrm{~nm}$, implicating UVB (280-315 nm) as an important mutagen in skin photo-carcinogenesis. Mutations are thought to be the first step in the induction of NMSC and have been reported to occur in genes encoding proteins such as the tumor suppressor protein p53 [9, 21]. Additionally, UV absorption by other chromophores in the skin can result in production of reactive oxygen species (ROS), which can cause damage to DNA, lipids, and proteins [22].

The DNA-damaging effects of cold injury caused by exposure to extremely cold temperatures have not been fully explored. Human and animal models have shown that the pathophysiology of frostbite involves 3 concurrent pathways of tissue freezing, hypoxia, and the release of inflammatory mediators. Tissue freezing causes damage to cell membranes and the osmotic release of water leading to cellular dehydration and cell death. Continued exposure to extreme cold induces local vasoconstriction and thrombosis resulting in tissue hypoxia. In the third pathway, the release of inflammatory mediators, such as prostaglandin 
PGF2 and thromboxane A2, stimulates more vasoconstriction and thrombosis, which exacerbate hypoxia and cell death [23]. Inflammatory mediators and cells such as neutrophils and mast cells have been shown to be upregulated in cold-injured skin [24].

In summary, both UVR and cold injury from extreme cold exposure can cause structural damage and inflammation in the skin. Inflammation has been associated with the development of cancer, with a proposed mechanism being modification to the DNA by ROS produced by infiltrating neutrophils and as a by-product of prostaglandin synthesis [25]. Indeed, ROS have been shown to cause a number of modifications to DNA, including mutations in the p53 gene [26]. Mast cells have also been associated with the promotion of skin tumor growth via the release of mediators that suppress the antitumor immune response and factors that promote tumor growth and survival [27]. Other changes that have been reported to occur in the skin following extreme cold exposure include an increase in cellularity and thickness of the granular cell layer of the epidermis and squamous metaplasia of the sweat glands [28, 29].

The high incidence of NMSC in many countries inflicts a significant burden on health care systems. The association between cold injury and NMSC has not been fully investigated and further research is necessary to determine if cold injury really can promote the development of NMSC and if so, what the mechanism is. Such research could advance scientific understanding of the harmful effects of cold injury and is particularly relevant for countries such as Kazakhstan where there is a high risk of frostbite from exposure to extremely low temperatures.

\section{Statement of Ethics}

We confirm that the patients have provided written informed consent to use their photos for publication.

\section{Disclosure Statement}

The authors have nothing to disclose.

\section{References}

1 World Health Organization: http://www.who.int/uv/faq/skincancer/en/index1.html. Accessed August 30, 2017.

2 Apalla Z, Lallas A, Sotiriou E, Lazaridou E, Ioannides D: Epidemiological trends in skin cancer. Dermatol Pract Concept 2017;7:1-6.

-3 Lomas A, Leonardi-Bee J, Bath-Hextall F: A systematic review of worldwide incidence of nonmelanoma skin cancer. Br J Dermatol 2012;166:1069-1080.

-4 Rogers HW, Weinstock MA, Harris AR, Hinkley MR, Feldman SR, Fleischer AB, Coldiron BM: Incidence estimate of nonmelanoma skin cancer in the United States, 2006. Arch Dermatol 2010;146:283-287.

5 Kazakh Research Institute of Oncology and Radiology: Cancer Incidence in the Republic of Kazakhstan 2015. Almaty, 2016, p 152.

-6 Fabbrocini G, Triassi M, Mauriello MC, Torre G, Annunziata MC, DeVita V, Pastore F, D'Arco V, Monfrecola G: Epidemiology of skin cancer: role of some environmental factors. Cancers (Basel) 2010;2:1980-1989.

-7 Lear JT, Tan BB, Smith AG, Bowers W, Jones PW, Heagerty AH, Strange RC, Fryer AA: Risk factors for basal cell carcinoma in the UK: case-control study in 806 patients. J R Soc Med 1997;90:371-374. 
-8 Brash DE, Rudolph JA, Simon JA, Lin A, McKenna GJ, Baden HP, Halperin AJ, Ponten J: A role for sunlight in skin cancer: UV-induced p53 mutations in squamous cell carcinoma. Proc Natl Acad Sci USA 1991;88:10124-10128.

9 Kim MY, Park HJ, Baek SC, Byun DG, Houh D: Mutations of the p53 and PTCH gene in basal cell carcinomas: UV mutation signature and strand bias. J Dermatol Sci 2002;29:1-9.

10 Corona R, Dogliotti E, D’Errico M, Sera F, Iavorone I, Baliva G, Chinni LM, Gobello T, Mazzanti C, Puddu P, Pasquini P: Risk factors for basal cell carcinoma in a Mediterranean population: role of recreational sun exposure early in life. Arch Dermatol 2001;137:1162-1168.

-11 Kricker A, Weber M, Sitas F, Banks E, Rahman B, Goumas C, Kabir A, Hodgkinson VS, van Kemenade CH, Waterboer T, Armstrong BK: Early life UV and risk of basal an squamous cell carcinoma in New South Wales, Australia. Photochem Photobiol 2017;93:1483-1491.

12 Burns EM, Guroji P, Ahmad I, Nasr HM, Wang Y, Tamimi IA, Stiefel E, Abdelgawwad MS, Shaheen A, Muzaffar AF, Bush LM, Hurst CB, Griffin RL, Elmets CA, Yusuf N: Association of vitamin D receptor polymorphisms with the risk on non-melanoma skin cancer in adults. JAMA Dermatol, DOI: 10.1001/jamadermatol.2017.1976.

13 Guo HR, Yu HS, Hu H, Monson RR: Arsenic in drinking water and skin cancers: cell-type specificity (Taiwan, ROC). Cancer Causes Control 2001;12:909-916.

14 Lichter MD, Karagas MR, Mott LA, Spencer SK, Stukel TA, Greenberg ER: Therapeutic ionizing radiation and the incidence of basal cell carcinoma and squamous cell carcinoma. The New Hampshire Skin Cancer Study Group. Arch Dermatol 2000;136:1007-1011.

15 Ulrich C, Kanitakis J, Stockfleth E, Euvrard S: Skin cancer in organ transplant recipients - where do we stand today? Am J Transplant 2008;8:2192-2198.

16 Patel RV, Clark LN, Lebwohl M, Weinberg JM: Treatments for psoriasis and the risk of malignancy. J Am Acad Dermatol 2009;60:1001-1017.

17 Rossis CG, Yiacoumettis AM, Elemenoglou J: Squamous cell carcinoma of the heel developing at site of previous frostbite. J R Soc Med 1982;75:715-718.

18 Eun HC, Kim JA, Lee YS: Squamous cell carcinoma in a frost-bite scar. Clin Exp Dermatol 1986;11:517520.

19 USA TODAY Health: Korean vets reveal cold truth about skin cancer. http://usatoday30.usatoday.com/news/health/spotlight/2001-05-25-frostbite.htm, 2001. Accessed July 2017.

20 Ullrich SE: Photoimmune suppression and photocarcinogenesis. Front Biosci 2002;7:d684-d703.

-21 Ziegler A, Leffell DJ, Kunala S, Sharma HW, Gailani M, Simon JA, Halperin AJ, Baden HP, Shapiro PE, Bale $\mathrm{AE}$, et al: Mutation hotspots due to sunlight in the p53 gene of nonmelanoma skin cancers. Proc Natl Acad Sci USA 1993;90:4216-4220.

-22 Chen AC, Halliday GM, Damian DL: Non-melanoma skin cancer: carcinogenesis and chemoprevention. Pathology 2013;45:331-341.

23 Johnson MP: Frostbite; in Ferri FF (ed): Ferri's Clinical Advisor. Elsevier, 2018, pp 502-503.

-24 Ozygan I, Tercan M, Melli M, Bekerecioglu M, Ustun H, Gunay GK: Eicosanoids and inflammatory cells in frostbitten tissue: prostacyclin, thromboxane, polymorphonuclear leukocytes, and mast cells. Plast Reconstr Surg 1998;101:1881-1886.

25 Oberyszyn TM: Non melanoma skin cancer: importance of gender, immunosuppressive status and vitamin D. Cancer Lett 2008;261:127-136.

26 Yu D, Berlin JA, Penning TM, Field J: Reactive oxygen species generated by PAH o-quinones cause change in function mutations in p53. Chem Res Toxicol 2002;15:832-842.

-27 Sarchio SN, Kok LF, O'Sullivan C, Halliday GM, Byrne SN: Dermal mast cells affect the development of sunlight induced skin tumours. Exp Dermatol 2012;21:241-248.

28 Bodey AS: Structural changes in the skin occurring in Antartica. Clin Exp Dermatol 1978;3:417-423.

-29 Schoning P: Experimental frost-bite in Hanford Miniature Swine. III. Sweat gland changes. Int J Exp Pathol 1990;71:713-716. 


\section{Case Reports in Dermatology}

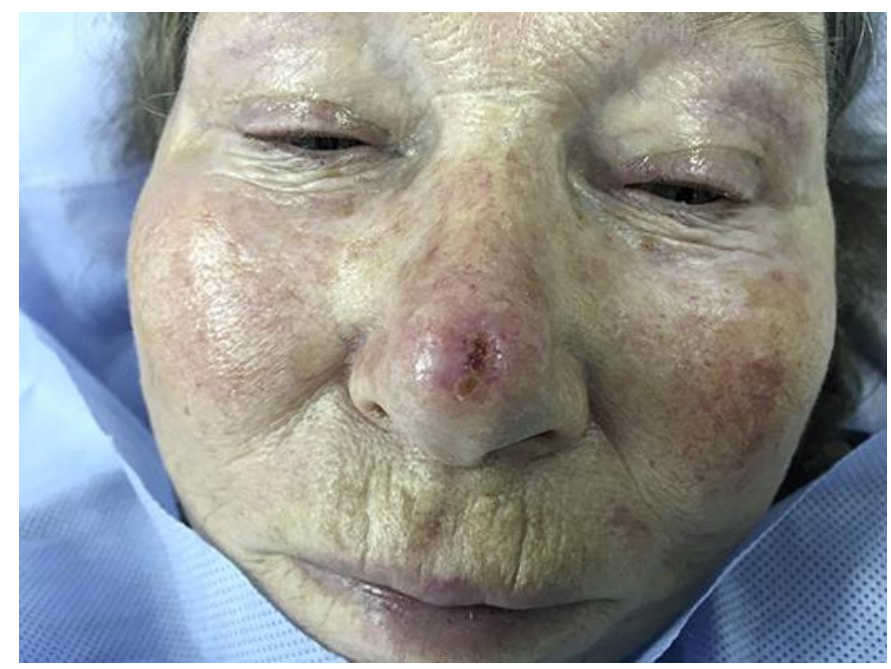

Fig. 1. Case 1.

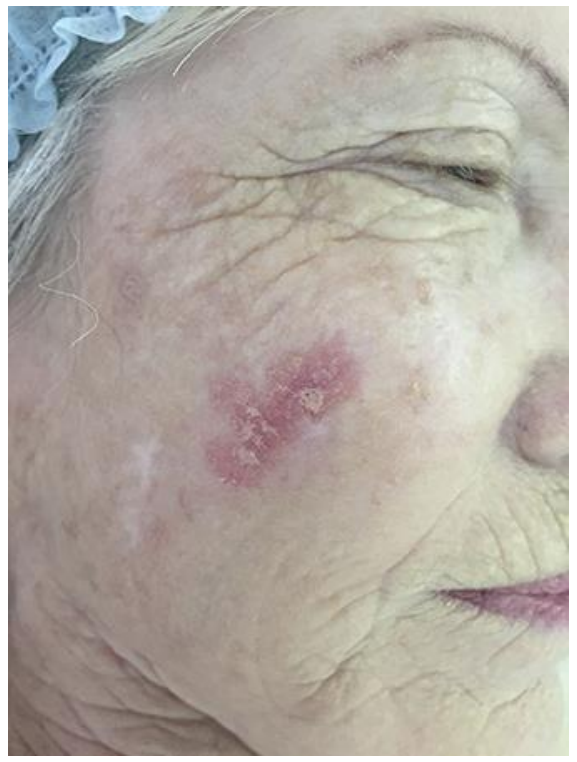

Fig. 2. Case 2.

Imanbayev et al.: Non-Melanoma Skin Cancers at Sites of Previous Frostbite: Case Report and Review www.karger.com/cde

\section{.}




\section{Case Reports in Dermatology}

www.karger.com/cde

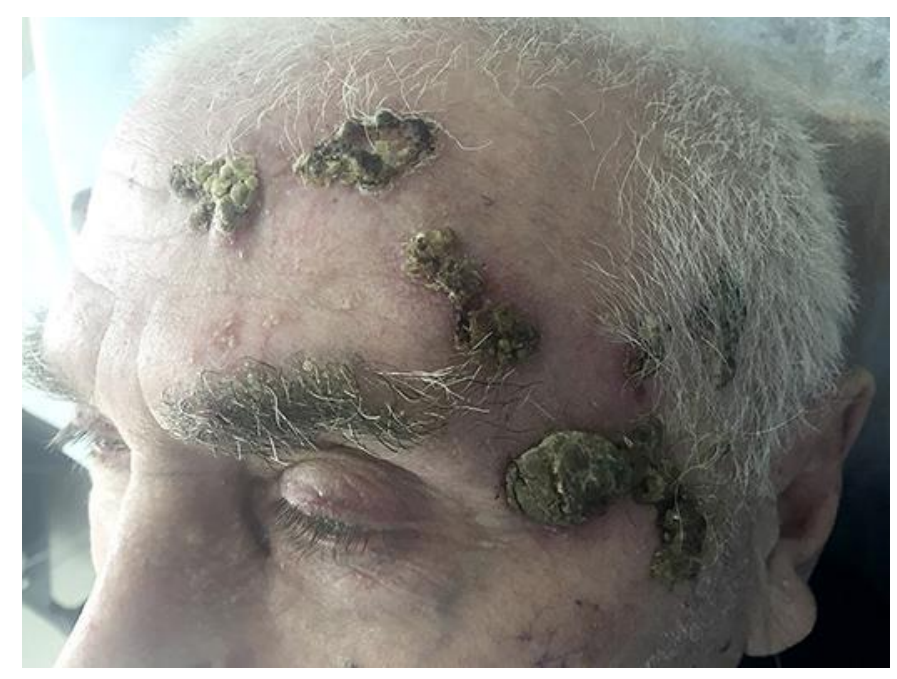

Fig. 3. Case 3 . Imanbayev et al.: Non-Melanoma Skin Cancers at Sites of Previous Frostbite: Case Report and Review 